\title{
Expression of E-cadherin in oral epithelial dysplasia and oral squamous cell carcinoma: An in vivo study
}

\author{
Oral epitelyal displazi ve oral yassı hücreli karsinomada E-cadherin ekspresyonu: In vivo bir \\ çalışma
}

\author{
Monal B. Yuwanati, J. V. Tupkari, Avadhoot Avadhani \\ Department of Oral pathology and Microbiology, Government Dental College \& Hospital, Mumbai, India
}

\begin{abstract}
Objectives: There is evidence that E-cadherins may also play a role in progression of dysplasia to cancer. The aim of this study was to investigate the expression of E-cadherin during the process of oral carcinogenesis by comparing their expression in normal and oral dysplastic epithelium (OED) with oral squamous cell carcinoma (OSSC).

Materials and methods: The patients who were clinical suspected of having premalignant lesion and oral squamous cell carcinoma were included in the study after the histopathological diagnosis. Totally 20 cases of OED and 20 Cases of OSSC were included in the study. From each case the following data were recorded: patient's age and sex, tumour location, TNM classification and clinical stage (I-IV). After preliminary examination of sections stained with haematoxylin/eosin, representative parts of each piece were selected and sectioned at 5 micron for immunohistochemical study.
\end{abstract}

Results: There was reduced expression of E-cadherin from mild to severe degree of dysplasia suggesting the negative correlation with E-cadherin expression. However, there was no significant correlation between E-cadherin expression, clinical TNM stage and prognosis score.

Conclusion: The E-cadherin expression is reduced with increase grade of dysplasia and in oral squamous cell carcinoma. The reduced expression of E-cadherin may be a reliable indicator of increase in invasiveness in oral squamous cell carcinoma. Reduced E-cadherin expression can be considered a useful marker for progression of dysplasia to oral cancer. J Clin Exp Invest 2011; 2 (4): 347-353

Key words: E-cadherin, oral epithelial dysplasia, oral squamous cell carcinoma

\section{ÖZET}

Amaç: E-cadherin'in displazinin kansere dönüşmesinde rol oynayabileceğine dair bulgular vardır. Bu çalışmanın amacı E-cadherin'in ağız içi normal mukoza, yassı epitel hücreli karsinom ve displastik epitelde ekspresyonunu karşılaştırarak oral karsinogenez ile ilişkisini araştırmaktır.

Gereç ve yöntem: Klinik olarak oral premalin lezyon ve yassı epitel karsinom şüphesi bulunan hastalar, histopatolojik tanıyı takiben çalışmaya alındı. Toplam olarak oral epitelyal displazili 20 hasta ve oral yassı epitel hücreli karsinomu bulunan 20 hasta çalışmaya alındı. Her hastada aşağıdaki değişkenler kaydedildi: Hastanın yaşı, cinsiyeti, tümör lokalizasyonu, TNM evresi ve klinik evre (I-IV). Hematoksilen-Eozin'le boyanmış kesitlerin ilk muayenesini takiben, her parçadan bir kısım alınarak 5 mikronluk kesitler halinde immunohistokimyasal çalışmaya alındı.

Bulgular: E-cadherin ekspresyonu ile displazi arasında negatif bir bağlantıyı telkin eder tarzda, hafiften ağıra değişen derecedeki displazide E-cadherin ekspresyonu azalmış bulundu. Ayrıca E-cadherin ekspresyonu ile klinik tümör evresi ve prognoz skoru arasında anlamlı bir bağıntı saptanmadı.

Sonuç: Oral yassı hücreli karsinomda displazi derecesi arttıkça E-cadherin ekspresyonu azalmaktadır. Azalmış E-cadherin ekspresyonu ağız içi yassı epitel hücreli karsinoma'da invazivlikte artışın güvenilir bir belirteci olabilir. Azalmış E-cadherin ekspresyonu displazini oral kansere dönüşmesini gösteren faydalı bir belirteç olarak düşünülebilir.

Anahtar kelimeler: E-cadherin, oral epitelyal displazi, oral yassı epitel hücreli karsinoma

Yazışma Adresi /Correspondence: Dr. Monal B Yuwanati

Dept. Oral pathology and Microbiology, Government Dental College, Mumbai-1, India Email: mon-al9817@gmail.com Geliş Tarihi / Received: 19.07.2011, Kabul Tarihi / Accepted: 10.09.2011

Copyright (C) Klinik ve Deneysel Araştırmalar Dergisi 2011, Her hakkı saklıdır / All rights reserved 


\section{INTRODUCTION}

Squamous cell carcinomas encompass at least $90 \%$ of all oral malignancies. ${ }^{1}$ It is the third most common malignancy in south-central Asia. Oral Squamous cell carcinoma (OSCC) implies quite significant mortality and morbidity rates. ${ }^{2}$ Most invasive oral carcinomas are preceded by a preinvasive stage, which may last for many years. During the progression there is loss of cohesion, it is result of defect at the cell adhesion molecular level. E-cadherin is one of the most important molecules in cell-cell adhesion in epithelial tissues. E-cadherin, expressed in most epithelial cells, is primarily responsible for the initial adhesion of these cells and also promotes cell polarity ${ }^{3,4,5}$ and the formation of specialized cell-cell junctions. ${ }^{6}$

E-cadherin is a $120 \mathrm{kDa}$ (KiloDalton) transmembrane glycoprotein and major cell-cell adhesion molecule. The cytoplasmatic moiety of E-cadherin binds to $\beta$ - and $\gamma$-catenin, which are linked to the cytoskeleton via $\alpha$-catenin, while the extracellular moiety is a calcium-dependent receptor responsible for homophilic (E-cadherin/E-cadherin) interactions. ${ }^{7}$ The first cadherin to be discovered are known as the 'classical' or type I cadherins. This includes E-cadherin and promotes calcium-dependent cell-cell adhesion via homophilic intercellular interactions. Classical cadherins are composed of five extracellular domains of 110 amino acids, which bind calcium ions (known as cadherin domains), a single transmembrane domain and two cytoplasmic domains. It is now well established that cadherins are not simply 'biological glues', but generate signals from the cell surface to influence a wide range of cell functions including apoptosis, growth factor receptor activation, tumour development and metastasis.

\section{Role of E- cadherin in normal cells}

Stable connections between cells play an essential role in overall tissue organization and function. Several adhesive structures are present in epithelial cells, including desmosomes (DS), hemidesmosomes (HDS) and zonula adherens (ZA). In the ZA, there are many cell junction proteins. The adhesion receptors present at the ZA are classic cadherins. In the epithelium, the ZA adhesion receptor is Ecadherin. The continued expression and functional activity of E-cadherins are required for cells to remain tightly associated in the epithelium. As far as normal adult epithelial tissue structure and integrity is concerned, E-cadherin is also involved in its maintenance and homeostasis. As already mentioned, its function lies primarily in the formation of adhe- rens junctions. Cadherin mediated adhesion is a dynamic process that is regulated by several signal transduction pathways. There is also evidence that cadherins are not only targets for signaling pathways that regulate adhesion, but may themselves send signals that regulate basic cellular processes, such as migration, proliferation, apoptosis and cell differentiation.

\section{Role of E-cadherin in malignant cells}

Progressive accumulation of somatic mutations in a number of different genes characterizes the process of tumorigenesis. Epithelial-mesenchymal conversion is also observed in malignant tumors of epithelial origin. This process is similar to developmental events but with the important difference that it is uncontrolled. Neoplastic cells are characterized in general by poor intercellular adhesion, loss of the differentiated epithelial morphology and increased cellular motility. Down regulation or complete shutdowns of E-cadherin expression, mutation of the E-cadherin gene, or other mechanisms that interfere with the integrity of the adherens junctions, are observed in neoplastic cells. In human tumors, the loss of E-cadherin-mediated cell adhesion correlates with the loss of the epithelial morphology and with the acquisition of metastatic potential by the neoplastic cells. Thus, a tumor invasion/suppressor role has been assigned to this gene.

Few studies have investigated the expression of the E-cadherin/catenin complex together and those studies of carcinomas from the head and neck have included infrequent examples of carcinomas from the oral cavity.

The aim of present study was to investigate the expression of E-cadherin during the process of oral carcinogenesis by comparing their expression in normal and oral dysplastic epithelium with oral squamous cell carcinoma.It was observed that there loss of E-cadherin expression in oral epithelial dysplasia (OED) and oral epithelial squamous cell carcinoma (OSCC). The present study provides insights into role of E-cadherin in progression of oral epithelial dysplasia toward the development of oral squamous cell carcinoma.E-cadherin is an "invasion suppressor" molecule and that in carcinogenesis loss of E- cadherins permits or enhances the invasion of adjacent normal tissue. ${ }^{8}$

\section{MATERIALS AND METHODS}

\section{Design and Case records}

This was a prospective study was carried out at Department of oral pathology, Government Dental 
College \& Hospital, Mumbai. The present hospital based study was carried out in the department. The Out Patient Department (OPD) patients were screened for premalignant lesion/s and oral cancer. The patients who were clinical suspected of having premalignant lesion and oral squamous cell carcinoma were included in the study after the histopathological diagnosis. Totally 20 cases of OED and 20 Cases of OSSC were included in the study. From each case record, we obtained the following data: patient's age and sex, tumour location, TNM classification and clinical stage (I-IV). After preliminary examination of sections stained with haematoxylin/eosin, representative parts of each piece were selected and sectioned at 5 micron for immunohistochemical study.

Oral epithelial dysplasia (OED) was graded as per the criteria given by Warnakulasurya et al. ${ }^{9} \mathrm{Mi}-$ croscopic Criteria used for diagnosing oral epithelial dysplasia is given in Table 1 .

The dysplastic changes were graded for each case according to following criteria into three grades mild, moderate and severe epithelial dysplasia. The grading of OSCC was done based on previously determined criteria (Table 2). ${ }^{10}$

Each of these features was scored from 1-4 according to definitions given by Anneroth. The total score was calculated. Based on these scores, each case was classified as good, moderate, poor. Prognosis was determined from the total malignancy score.

Grading score: 5-8 (good) 9-12 (moderate) 1320 (poor)

Table 1. Criteria for Oral epithelial dysplasia

\begin{tabular}{ll}
\hline Architecture & Cytology \\
\hline Irregular epithelial stratification & Abnormal variation in nuclear size (anisonucleosis) \\
Loss of polarity of basal cells & Abnormal variation in nuclear shape (nuclear pleomorphism) \\
Basel cell hyperplasia & Abnormal variation in cell size (anisocytosis) \\
Drop-shaped rete ridges & Abnormal variation in cell shape (cellular pleomorphism) \\
Increased number of mitotic figures & Increased nuclear-cytoplasmic ratio \\
Abnormally superficial mitoses & Increased nuclear size \\
Pre-mature keratinization in single cells (dyskeratosis) & Atypical mitotic figures \\
Keratin pearls within rete ridges & Increased number and size of nucleoli Hyperchromasia \\
\hline
\end{tabular}

Table 2. The grading criteria of oral epithelial squamous cell carcinoma ${ }^{10}$

\begin{tabular}{|c|c|c|c|c|}
\hline Morphologic feature & 1 & 2 & 3 & 4 \\
\hline Degree of keratinization & $\begin{array}{l}\text { Highly keratinized } \\
\text { (>50\% of the cells) }\end{array}$ & $\begin{array}{l}\text { Moderately keratinized } \\
(20-50 \% \text { of the cells) }\end{array}$ & $\begin{array}{l}\text { Minimal keratinization } \\
\text { (5-20\% of the cells) }\end{array}$ & $\begin{array}{l}\text { No keratinization } \\
\text { (0-5\% of the cells) }\end{array}$ \\
\hline Nuclear polymorphism & $\begin{array}{l}\text { Little nuclear } \\
\text { Polymorphism } \\
\text { (> 75\% mature cells) }\end{array}$ & $\begin{array}{l}\text { Moderately abundant } \\
\text { nuclear polymorphism } \\
\text { (50-75\% mature cells) }\end{array}$ & $\begin{array}{l}\text { Abundant nuclear } \\
\text { polymorphism } \\
\text { (25- } 50 \% \text { mature cells) }\end{array}$ & $\begin{array}{l}\text { Extreme nuclear } \\
\text { Polymorphism } \\
(0-25 \% \text { mature cells) }\end{array}$ \\
\hline $\begin{array}{l}\text { Number of mitosis } \\
\text { ( high power field) }\end{array}$ & $0-1$ & $2-3$ & $4-5$ & $>5$ \\
\hline Pattern of invasion & $\begin{array}{l}\text { Pushing, well } \\
\text { delineated infiltrating } \\
\text { borders }\end{array}$ & $\begin{array}{l}\text { Infiltrating solid } \\
\text { cords bands and } \\
\text { or strands }\end{array}$ & $\begin{array}{l}\text { Small groups or } \\
\text { cords of infiltrating } \\
\text { cells }(n>15)\end{array}$ & $\begin{array}{l}\text { Marked wide spread } \\
\text { cellular dissociation } \\
\text { in small groups and/or } \\
\text { in single cells }(n>15)\end{array}$ \\
\hline $\begin{array}{l}\text { Lymphoplasmocytic } \\
\text { infiltration }\end{array}$ & Marked & Moderate & Slight & None \\
\hline
\end{tabular}




\section{Immunohistochemistry}

Five $\mu \mathrm{m}$ sections were cut from archive paraffin blocks and mounted on super frost slides. Immunocytochemical staining was carried out using a streptavidin Avidin-Biotin complex (ABC) labeling technique and visualized with diaminobenzidine tetrahydrochloride (DAB). Sections were dewaxed, washed in alcohol and antigen was retrieved by microwaving in citric acid ( $\mathrm{pH} \mathrm{6)}$ for $30 \mathrm{~min}$. Sections were then washed in PBS. Endogenous peroxidase was blocked using $1 \%$ hydrogen peroxide in methanol at room temperature for $10 \mathrm{~min}$. Slides were washed in PBS briefly and incubated with primary antibody at dilutions 1:100 indicated for 40 $\mathrm{min}$. Slides were then washed in PBS for $5 \mathrm{~min}$ and incubated with secondary antiserum that was biotinylated goat serum covalent to rabbit and mouse serum for $30 \mathrm{~min}$. Sections were then washed for 5 min in PBS followed by the streptavidin-biotin complex Following a wash in PBS, the peroxidase was then visualised by using $0.18 \mathrm{~g} \mathrm{DAB} / 300 \mathrm{ml}$ PBS with $30 \mathrm{ml}$ of hydrogen peroxide for $8 \mathrm{~min}$. Sections were then washed, counterstained with haematoxylin, washed in water and Scotts solution, dehydrated and then mounted. Normal gingiva was used as the positive control and negative controls were prepared by omitting the primary antibody.

\section{Evaluation of immunoreactivity}

Intensity of membranous staining was assessed using a semi quantitative, previously validated, method. ${ }^{11}$ Immunoreactivity was assessed with respect to cellular localization (membranous). A scale of 0 to +++ was used, +++ being strong, ++ moderate and + being mild membranous staining. 0 indicated absence of staining. ${ }^{12}(3+=$ complete stain of the cellular membrane for more than $50 \%$ of the stained cells, $2+=$ staining between $10 \%$ and $50 \%$ of cells, $1+=$ less than $10 \%$ of stained cells, $0=$ stain absence). The pattern of immunostaining for E-cadherin was described as normal when complete membranous staining was observed. In relation to immunostaining within the epithelium, the various compartments within the epithelium were described as basal, suprabasal and superficial cell layers. Stained slides were examined under high power (40X) of microscope. This was followed by counting of cells. Random ten high power fields were selected. Hundred cells were counted in each field in a zigzag fashion. Thus, the total numbers of cells counted per slide were one thousand. All samples were evaluated by a single person blinded to sample characteristics.

\section{Statistical analysis}

It was performed using Statistical Package for the Social Sciences (SPPS) computer program v.17.0 for Windows XP. Mann-Whitney test, Kruskall Wallis test, Spearman's rank correlation coefficient were used for statistical analysis. A p value less than 0.05 was regarded as statistically significant.

Table 3. Expression of E-cadherin in oral epithelial dysplasia

\begin{tabular}{lccc}
\hline E-cadherin expression & \multicolumn{3}{c}{ Degree of dysplasia } \\
\cline { 2 - 4 } & Mild & Moderate & Severe \\
\hline 0 (Absent) & 0 & 0 & 0 \\
$+1(n=0)$ & 0 & 0 & 0 \\
$+2(n=6)$ & 1 & 0 & 5 \\
$+3(n=14)$ & 9 & 3 & 2 \\
\hline Total $(n=20)$ & 10 & 3 & 7 \\
\hline
\end{tabular}

Table 4. Prognosis score and E-cadherin expression in OSCC

\begin{tabular}{lccc}
\hline E-cad expression & \multicolumn{3}{l}{ Prognosis score } \\
\cline { 2 - 4 } & $\begin{array}{c}\text { Good } \\
(n=14)\end{array}$ & $\begin{array}{c}\text { Moderate } \\
(n=4)\end{array}$ & $\begin{array}{c}\text { Poor } \\
(n=2)\end{array}$ \\
\hline $0(n=2)$ & 0 & 0 & 2 \\
$+1(n=3)$ & 2 & 1 & 0 \\
$++2(n=15)$ & 12 & 3 & 0 \\
$+++3(n=0)$ & 0 & 0 & 0 \\
\hline Total $(n=20)$ & 14 & 4 & 2 \\
\hline
\end{tabular}

Table 5. Expression of E-cadherin and clinical TNM staging

\begin{tabular}{cccccc}
\hline & & \multicolumn{3}{c}{ Expression of E-cadherin } \\
\cline { 3 - 6 } TNM stage & $\begin{array}{c}\text { Number of } \\
\text { cases }\end{array}$ & 0 & +1 & +2 & +3 \\
\hline Stage I $(n=2)$ & 2 & 0 & 0 & 2 & 0 \\
Stage II $(n=4)$ & 3 & 0 & 1 & 2 & 1 \\
Stage III $(n=12)$ & 13 & 0 & 4 & 8 & 0 \\
Stage IV $(n=2)$ & & & & & \\
A & 1 & 0 & 0 & 1 & 0 \\
B & 1 & 0 & 0 & 0 & 0 \\
C & & 0 & 0 & 1 & 0 \\
\hline Total $(n=20)$ & 20 & 0 & 5 & 14 & 1 \\
\hline
\end{tabular}




\section{RESULTS}

\section{Oral epithelial dysplasia (OED)}

Out of 20 cases of oral epithelial dysplasia, 10 were mild, 3 were moderate and 7 were severe cases (Table 3). E-cadherin immunoreactivity was moderate positivity in 6 cases $(30 \%)$, strong positivity in 14 cases $(70 \%)$. Negative or weak E-cadherin immunoreactivity was not observed in case of OED. Mean score for OSCC was 1.7 and in cases of OED 2.7. The reduced expression of E-cadherin was observed from mild degree to severe degree. The Ecad expression was significantly low $(P<0.0001)$ in severe degree of dysplasia as compared to mild to moderate degree. Thus, there was reduced expression of E-cadherin from mild to severe degree of dysplasia suggesting the negative correlation with E-cadherin expression (Spearman's correlation coefficient ' $r$ '=0.065) (Figure 1, 2, 3).

\section{Oral squamous cell carcinoma (OSCC)}

In the normal oral mucosa, intense E-cadherin immunoreactivity was observed in the basal $2 / 3$ of the epithelium, but not on the basal surface of basal cells. In mucosa adjacent to tumours (epithelium showing epithelial dysplasia), E-cadherin immunoreactivity was reduced (with respect to normal mucosa) in the basal and suprabasal layers. Within tumours, E-cadherin immunoreactivity was absent/ negative in 2 cases (10\%), weak in 3 cases $(15 \%)$, moderate in 15 cases $(75 \%)$ (Table 4$)$. There was reduced expression of E-cadherin in oral squamous cell carcinoma which was statically significant (P-0.0001 \& 'r'=-0.486) (Figure 4, 5, 6).

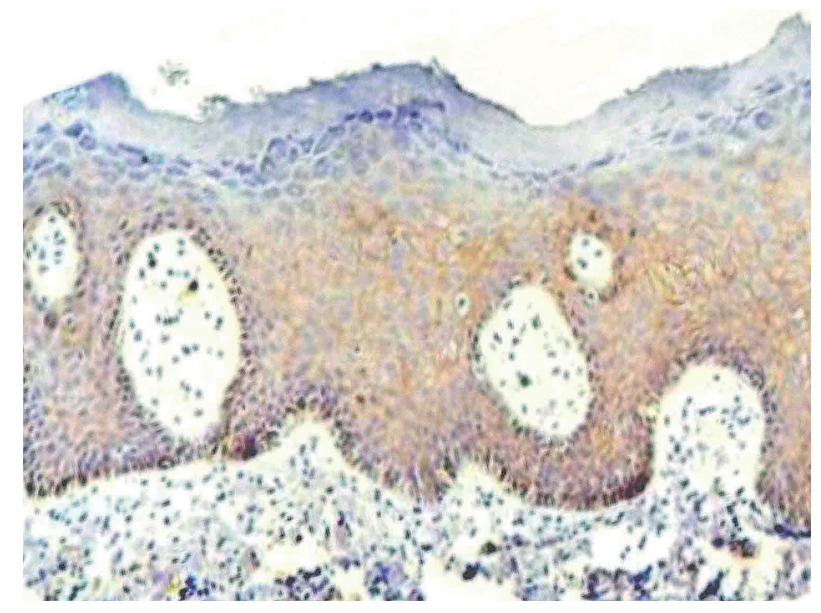

Figure 1. E-cadherin immunohistochemical expression Mild epithelial dysplasia (10X)

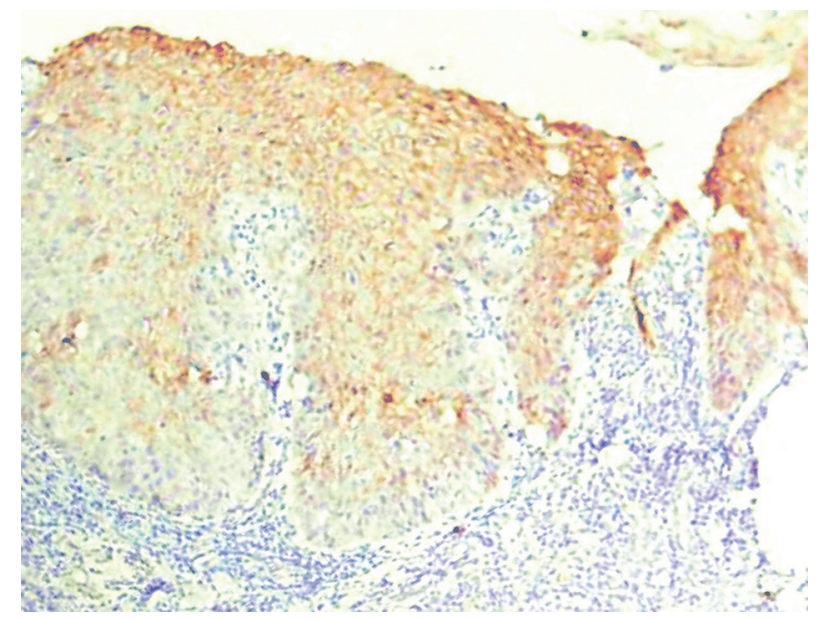

Figure 2. E-cadherin immunohistochemical expressionE-cadherin score - 0(10X)

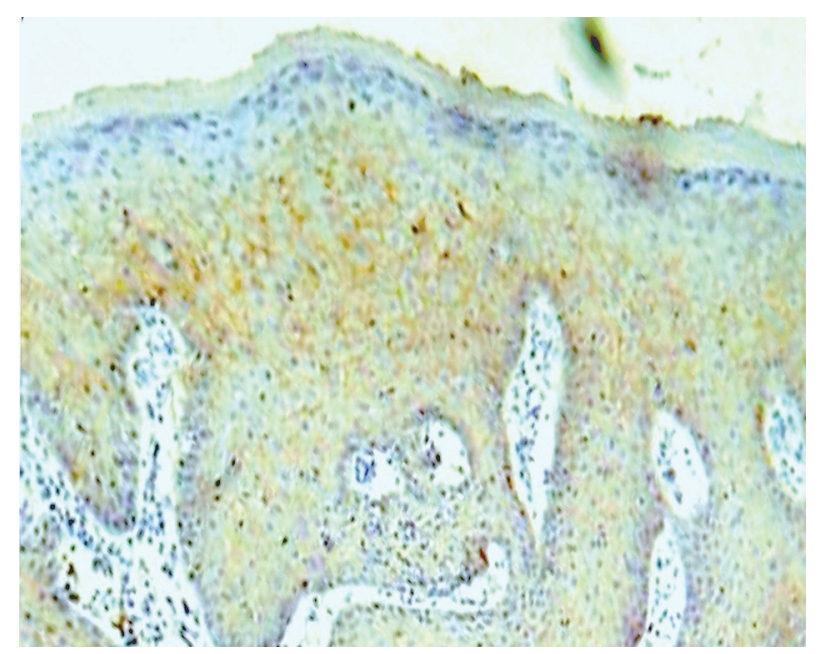

Figure 3. E-cadherin immunohistochemical expressionE-Cadherin Score- +1(10X)

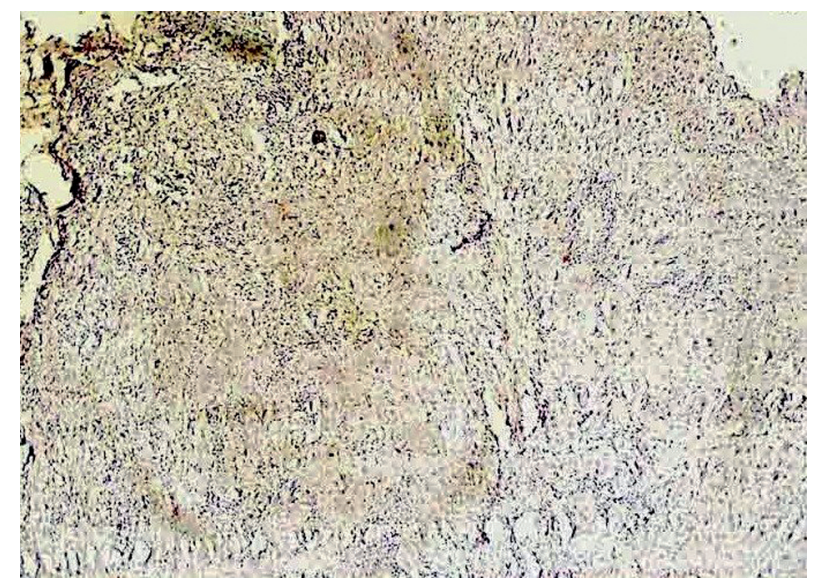

Figure 4. E-cadherin immunohistochemical expressionSevere Epithelial Dysplasia (10x) 


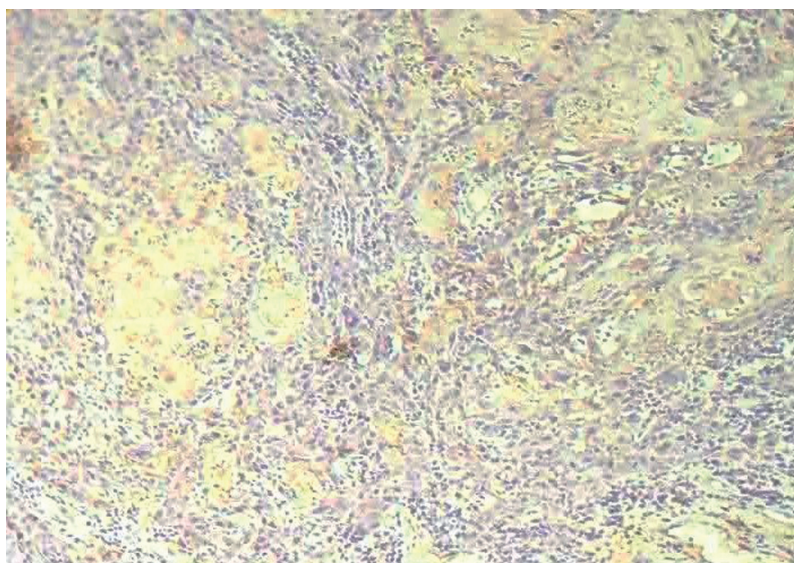

Figure 5. Moderate epithelial dysplasia (10x)

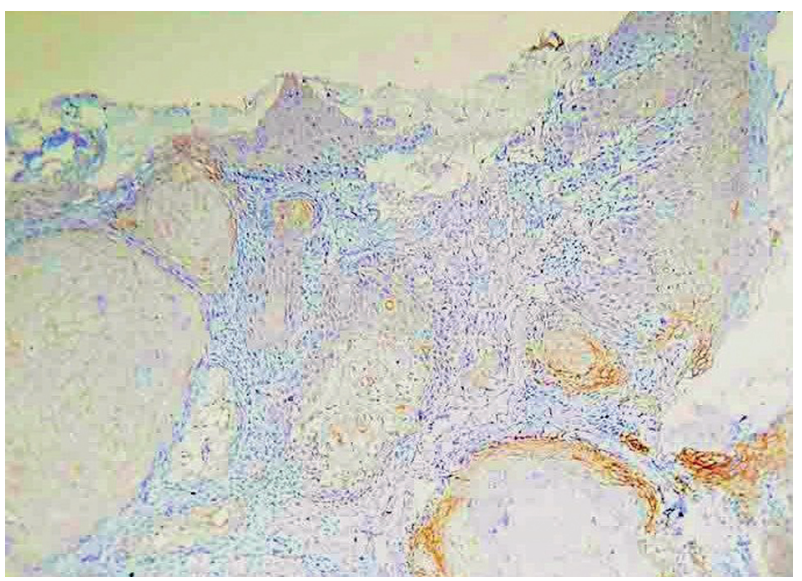

Figure 6. E-cadherin immunohistochemical expressionE-Cadherin Score - ++2(10X)

\section{Correlation between E-cadherin expression and clinical TNM staging}

Out of 20 cases of Oral squamous cell carcinoma, 2 cases were in T1 stage, 4 cases in T2 and 12 in T3 and 2 cases in T4 (Table 4). Out this 5 cases were showing weak expression, moderate were in 14 cases and strong expression was present in only one case (Table 5). Nonparametric test showed no significant correlation (Spearman's correlation coefficient ' $r$ ' $=0.15$ ) between E-cadherin expression and TNM stage.

\section{Expression of E-cadherin and Prognosis score}

According to Bryne et al grading criteria10, Out of 20 cases of squamous cell carcinoma, 13 cases showed good prognosis, 5 were having moderate prognosis whereas 2 cases were showing poor prognosis (Table 2) Expression of E-cadherin was higher in patient with good and moderate prognosis than the poor prognosis (P- 0.017). Statistical analysis showed Negative correlation (Spearman's correlation coefficient ' $r$ ' $=-0.486$ ) between the Ecadherin expression and prognosis score based on the histopathologic findings.

\section{DISCUSSION}

Head and neck squamous cell carcinoma (HNSCC) is one of the most common cancers on a worldwide basis with a higher incidence. According to the existing molecular model for carcinogenesis in head and neck squamous cell carcinoma, ${ }^{13}$ this malignancy arises from a multistep process in which genetic events lead to the disruption of the normal regulatory pathways that control basic cellular functions including cell division, differentiation and cell death. E-cadherin is a key molecule for the maintenanceof intracellular adhesion and down-regulation of this protein has been associated with tumour progression in diverse human cancer types.

In the present study, it was observed that there is reduction in E-cadherin in oral epithelial dysplasia as severity of dysplasia is increased. This reduction of E-cadherin was in line with that of the observation of the previous studies. ${ }^{12,19}$ In the mild and moderate degree of dysplasia, loss of E-cadherin was less as compared to severe degree of dysplasia. The loss of E-cadherin mediated cell adhesion correlates with the loss of the epithelial morphology. The Ecadherin expression in mild epithelial dysplasia was present in supra basal and basal similar to the normal epithelium. ${ }^{14}$ In moderate epithelial dysplasia, E-cadherin expression was present in supra basal but expression was reduced in the basal cell layer. This loss leads to acquisition of invasive property by the basal cell. ${ }^{15}$

The reduced expression of E-cadherin was observed in the oral squamous cell carcinoma. The e-cad expression was decreased with increase pleomorphism, which, was correlating with histopathological findings. Thus the reduced E-cadherin expression has significant role in development of oral squamous cell carcinoma from oral epithelial dysplasia.

Yamada et al16, Bowie et al17 and Jun Man Kim et al18 also found the correlation between reduced expressions of E-cadherin with TNM clinical staging. The lack of correlation was observed between the reduced $\mathrm{E}$-cadherin expression and clinical TNM staging in the current study, as CT/MRI was not done for detection of extent of the lesion and metastasis due to availability and cost factor. 
It is evident from the present study results that E-cadherin plays role in processes of carcinogenesis, which is confirmed by reduced expression in oral epithelial dysplasia and oral squamous cell carcinoma. It can be used as tumor suppressor gene as previously indicated. Also clinical stage and Prognosis based on the histological findings showed no correlation with E-cadherin expression.

\section{REFERENCES}

1. World Health Organization. The World Oral Health Report 2003. Geneva: World Health Organization; 2003. pp. 6-7

2. Massano J, Regateiro FS, Januário G, Ferreira A. Oral squamous cell carcinoma: review of prognostic and predictive factors. Oral Surg Oral Med Oral Pathol Oral Radiol Endod 2006;102(1):67-76

3. Shirayoshi Y, Okada TS, Takeichi M. The calcium-dependent cell-cell adhesion system regulates inner cell mass formation and cell surface polarization in early mouse development. Cell 1983; 35(5): 631-8.

4. Sutherland A. Mechanisms of implantation in the mouse: differentiation and functional importance of trophoblast giant cell behavior. Dev Biol 2003;15;258(2):241-51.

5. McNeill H, Ozawa M, Kemler R, Nelson WJ. Novel function of the cell adhesion molecule uvomorulin as an inducer of cell surface polarity. Cell 1990;27;62(2):30916.

6. Boller K, Vestweber D, Kemler R. Cell-adhesion molecule uvomorulin is localized in the intermediate junctions of adult intestinal epithelial cells. J Cell Biol 1985;100(1):327-32.

7. Takeichi M. Morphogenetic roles of classic cadherins. Curr Opin Cell Biol 1995;7(5):619-27.

8. Christofori G, Semb H. The role of the cell-adhesion molecule E-cadherin as a tumour-suppressor gene. Trends Biochem Sci 1999;24(2):73-6.

9. Warnakulasuriya S, Reibel J, Bouquot J, Dabelsteen E. Oral epithelial dysplasia classification systems: predictive value, utility, weaknesses and scope for improvement. J Oral Pathol Med 2008; 37(3):127-133.
10. Bryne M, Nielsen K, Koppang HS, Dabelsteen E. Reproducibility of two malignancy grading systems with reportedly prognostic value for oral cancer patients. J Oral Pathol Med 1991;20(8):369-72.

11. Jankowski J, Newham $P$, Kandemir O, Hirano S, Takeichi M, Pignatelli M. Differential expression of E-cadherin in normal, metaplastic and dysplastic esophageal mucosa - a putative biomarker. Int $\mathrm{J}$ Oncol 1994;4(2):441-8.

12. Santos-García A, Abad-Hernández MM, FonsecaSánchez E, et al. E-cadherin, laminin and collagen IV expression in the evolution from dysplasia to oral squamous cell carcinoma. Med Oral Patol Oral Cir Buccal. 2006;1;11(2):E100-5.

13. Califano J, van der Riet P, Westra W, et al. Genetic progression model for head and neck cancer: implications for field cancerization. Cancer Res 1996;56(11):248892.

14. Hiraguri S, Godfrey T, Nakamura H, et al. Mechanisms of inactivation of E-Cadherin in Breast Cancer Cell Lines. Cancer Res 1998;58(9):1972-7.

15. Kudo Y, Kitajima S, Ogawa I, et al. Invasion and metastasis of oral cancer cells require methylation of E-Cadherin and or degradation of membranous bCatenin. Clin Cancer Res 2004;10(16):5455-5463.

16. Yamada K, Jordan R, Mori M, Speight PM. The relationship between E-cadherin expression, clinical stage and tumour differentiation in oral squamous cell carcinoma. Oral Dis 1997;3(2):82- 85.

17. Bowie GL, Caslin AW, Roland NJ, Field JK, Jones AS, Kinsella AR. Expression of cell-cell adhesion molecule E-cadherin in squamous cell carcinoma of head and neck. Clin Otolaryngol Allied Sci 1993;8(3);196-201.

18. Kim JM et al, Expression of E-cadherin and clinical correlation in patients with breast carcinoma. J Korean Breast Cancer Soc 2004;7(1):148-53.

19. Williams HK, Sanders DS, Jankowski JA, Landini G, Brown AM. Expression of E-cadherin in oral epithelial dysplasia and squamous cell carcinoma J Oral Pathol Med 1998;27(7):308-17. 